\title{
RIFT VALLEY FEVER IN RURAL NORTHERN SENEGAL: HUMAN RISK FACTORS AND POTENTIAL VECTORS
}

\author{
MARK L. WILSON, LOUISA E. CHAPMAN, DAVID B. HALL, ELIZABETH A. \\ DYKSTRA, KHALILOU BA, HERVE G. ZELLER, MOUMOUNI TRAORE-LAMIZANA, \\ JEAN-PAUL HERVY, KENNETH J. LINTHICUM, AND C. J. PETERS \\ Institut Pasteur, Dakar, Senegal; Centers for Disease Control and Prevention, Atlanta, Georgia, \\ Institut Francais de Recherche Scientifique pour le Developpement en Cooperation (ORSTOM), \\ Dakar, Senegal; U. S. Army Medical Research Institute of Infectious Diseases, \\ Frederick, Maryland
}

\begin{abstract}
To investigate past infection in and transmission of Rift Valley fever (RVF) virus to humans within an endemic focus, we undertook a retrospective cohort study of the seminomadic Peul people living in sub-Saharan northcentral Senegal. Residents of the rural settlement of Yonofere five years of age or older were studied during February-May 1989. Anti-RVF virus IgG was found in blood samples of $22.3 \%$ of 273 persons who responded to a standard questionnaire; none had IgM antibodies. Seropositivity was similar for males $(25.4 \%)$ and females $(21.1 \%)$, increased markedly with age for both sexes, and varied considerably among compounds (groups of huts) (0-37.5\%). Risk factors for past RVF virus infection were nursing sick people, assisting animals during abortions/births, and treating sick animals. In all age groups, odds ratios (ORs) for RVF viral antibody among females who reported treating sick animals were three to six times greater than for those who did not. The ORs for males who reported assisting with animal births/abortions and nursing sick people were approximately five times those for males who did not. Serologic prevalence of RVF viral antibody among sheep averaged $30.1 \%$ overall $(0.8 \%$ IgM), but varied among compounds (0-66.7\%) in a manner different from that of humans. The seasonal abundance and relative density of potential mosquito vectors were estimated by monthly samples captured in Centers for Disease Control and Prevention-type traps. Mosquito abundance varied seasonally with rainfall ( $>90 \%$ captures during four months). Species diversity was large (28 spp.), dominated by Aedes and Culex. Rift Valley fever virus was not isolated from 142 pools of 2,956 unengorged mosquitoes tested, although three other arboviruses were found. Results indicate that RVF is endemic in this region, people are at considerable risk of infection, and that a heretofore unrecognized mode of human infection under nonepizootic conditions may be transmission via contact with infected animals or humans.
\end{abstract}

Rift Valley fever (RVF) is an acute viral illness of humans and domestic ungulates. Human disease initially is characterized by abrupt onset of high fever, severe headache, myalgia, conjunctival injection, and incapacitating prostration of several days duration., ${ }^{1,2}$ Some patients develop fatal hemorrhagic fever, or late compli-. cations of encephalitis or ocular disease (primarily retinal vasculitis). The RVF virus also causes severe disease in domestic ungulates, particularly sheep and cattle. ${ }^{3,4}$ Such infection often provokes fetal abortion and frequently is fatal to young animals.

Transmission of this phlebovirus (family Bunyaviridae) has been documented in at least 24 countries throughout Africa. ${ }^{1-4}$ Even where endemic, however, elevated transmission of RVF virus appears sporadically in time and space.
Occasional epidemics and epizootics have been recognized since the 1930 s in eastern Africa ${ }^{5,6}$ and since the 1950s in southern parts of the continent. ${ }^{3,4}$ In West Africa, however, large-scale RVF outbreaks had not been reported prior to the 1987 epidemic in southern Mauritania, ${ }^{7-9}$ despite virologic or serologic evidence of virus circulation there ${ }^{10}$ and in Nigeria, ${ }^{11}$ Burkina Faso, ${ }^{12}$ Guinea, ${ }^{13} \mathrm{Mali},{ }^{14}$ and Senegal. ${ }^{13},{ }^{15}$ The Mauritanian epidemic finally demonstrated the devastating potential of RVF in West Africa and raised new questions concerning the ecologic factors important to transmission in that environment.

Infected mosquitoes are thought to represent the principal means by which RVF virus is transmitted zoonotically, ${ }^{16-18}$ although human infections also may result during animal slaughter, food preparation, and necropsy or laboratory-ex 
perimentation. ${ }^{10-21}$ Potential vectors include more than 30 African mosquito species from which RVF virus has been isolated.2 Experimental and field studies suggest that certain flood water Aedes spp. that emerge from temporary ground pools after heavy rains are important enzootic vectors. 22 Epizootic transmission, which in East Africa is correlated temporally with years of heavy rainfall, 23 may occur when particular Culex spp. become infected. ${ }^{1 ?}{ }^{18}$ Transmission to humans could be associated with certain species that also bite people. ${ }^{2+}$

These concepts derive from observations made primarily during epidemics or epizootics in eastern and southern Africa: little is known concerning the epidemiology of endemic transmission of RVF virus in the western part of the continent. Furthermore, no systematic analysis of potential risk factors for human infection has yet been reported. Accordingly, we undertook a retrospective, questionnaire-based, cohort study among the Peul (Fulani) people living in a rural settlement in northcentral Senegal. This area, located about $200 \mathrm{~km}$ southeast of the Mauritanian site where the recent epidemic RVF occurred, is known for enzootic transmission.9. 13,15 Our study analyzed the prevalence of RVF viral antibody in humans and their sheep and questioned people about possible factors that may have placed them at risk of RVF. In addition. we sampled mosquitoes at this site to determine the relative abundance and seasonal activity of potential RVF virus vectors.

\section{MATERIALS AND METHODS}

Study site. Our investigation was conducted in rural northcentral Senegal within the village of Yonofere $\left(15^{\circ} 14^{\prime} \mathrm{N}, 14^{\circ} 29^{\prime} \mathrm{W}\right.$ ) (Figure 1). This site, as well as most of our methods, has been described previously. ${ }^{25}$ The region, identified as the Ferlo, is predominantly grassy, shrubby thornbush habitat classified as Sahelo-Sudanian savannah. ${ }^{26,27}$ Rainfall averages $500 \mathrm{~mm}$ annually, may vary considerably from year to year, and occurs in a strictly seasonal pattern. principally July-September. ${ }^{28}$ During the typical nine-month dry season. no standing water is available and a large well serves as the primary water source for people and animals within a 25$\mathrm{km}$ radius. In addition to the permanent residents of the village, other people, principally nomadic Maur herders, usually migrate through the re- gion each year, moving tens of thousands of domestic ungulates southward during the dry season. returning northward when the rains recommence..$^{27}$

Village inhabitants were predominantly Muslims of the Peul (Fulani) ethnic group. ${ }^{27.29}$ They: lived in simple. millet-stalk huts grouped into clusters (compounds) consisting of extended families, each typically composed of a married man (the compound's chief). his wife or wives, and various dependents ( $\sim 6-25$ persons). Residents grew millet during the rainy season and herded sheep. goats, and cattle year-round. Animal herding varied seasonally. During the rainy season. when forage and standing water are readily available. herds were kept in close proximity $(\sim<5 \mathrm{~km})$ to their compounds. As the dry season progressed. local forage became sparse and animals were duriven over increasingly greater distances, often traversing $10-30 \mathrm{~km}$ a day. The extent of movement generally is restricted. however, by the distribution of water wells; family groups and their herds may become seasonal nomads, temporarily relocating for a few months during which they use grass huts for shelter. ${ }^{27}$

Study cohort. Persons at least five years old who resided within a $10-\mathrm{km}$ radius of the central village well during February-May 1989 were considered eligible participants. The total population of such residents of the study area was estimated by a census of all compounds present during any portion of the study period. Compound chiefs then were asked for their informed consent that members of the compound could participate. Of 52 compound chiefs who were contacted (63\% of those in the village). 36 $(69 \%)$ agreed to enroll their compound. Individuals could refuse participation at anytime during the study.

Blood samples and analysis. A single blood specimen was obtained from each consenting compound resident. In addition, we obtained the permission of sheep owners to bleed adult animals that were more than one year old. During February-May 1989. the entire population of adult sheep was sampled in most flocks. For large flocks, or for those whose owner did not give permission to bleed certain animals, a subsample chosen by the shepherd was bled. Blood samples were drawn into Vacutainer (Becton Dickinson. Rutherford. NJ) tubes, held at ambient temperature in the field for 1-9 days, and 

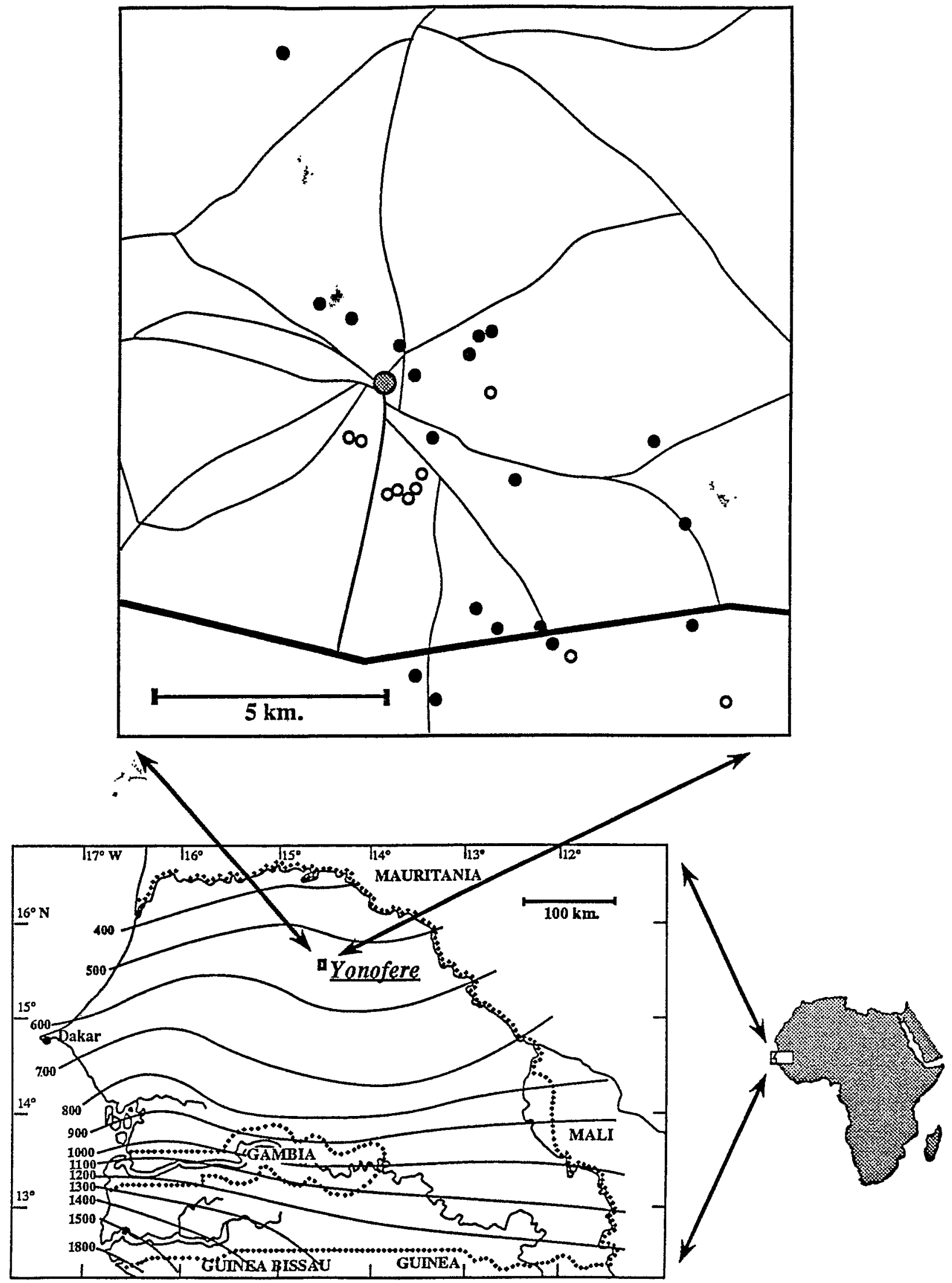

FIGURE 1. Map of Yonofere, Senegal, in relation to various features of West Africa. Average annual rainfall isoyhets (mm) and surrounding countries are shown below. Circles indicate surveyed compounds whose location was established (solid) or temporary (open) as well as dwellings near the village well (large hatched circle). Principal dirt roads are also shown. 
then centrifuged: serum was stored at $-20^{\circ} \mathrm{C}$ in Dakar. Serum samples were tested at the Pasteur Institute in Dakar for RVF virus-specific IgG and IgM antibodies by enzyme-linked immunosorbent assays that have been previously described. ${ }^{y, 30.31}$

Questionnaires. Three questionnaires were used to obtain information for the study. Two were administered only to the compound chiefs: the first sought information on the name, sex. age. primary sleeping hut, and kinship patterns of every resident within each chief's compound. and the second asked about activities within each chief"s compound during the past two years that might be associated with RVF (e.g., animal husbandry practices, nomadic activities, recent deaths, etc.) The third questionnaire, administered to all consenting compound members and compound chiefs. requested information about each individual's demographic characteristics. personal health, and putative risk factors resulting from meat preparation and consumption. agricultural activities, animal care, providing health care, travel, and other daily activities.

Questionnaires were administered in the Peullar language by two Senegalese men and an American woman. The compound chief was always questioned by a man: other adults were questioned singly, usually by an interviewer of the same sex. Children less than 12 years of age were questioned in the presence of an adult compound member.

Mosquito samples. The variety and seasonal abundance of mosquitoes were studied by monthly trapping during July 1989 through June 1991. Four Centers for Disease Control and Prevention-type light traps baited with $1 \mathrm{~kg}$ of dry ice were set from dusk to dawn at the same sites once each month near the village chief's compound. Two traps were placed $\sim 10 \mathrm{~m}$ from inhabited huts on opposite ends of the compound. The other two traps were stationed at the edges of two rainfed depressions located $500 \mathrm{~m}$ and $600 \mathrm{~m}$ from the compound. These temporary. seasonal pools, known as vendus in Peullar, are geomorphologically and biologically similar to the shallow depressions called dambos of East Africa. ${ }^{32-35}$ Each vendu covered $\sim 0.5-2$ hectares, but contained shallow $(\sim<1 \mathrm{~m})$ stagnant water solely during the rainy season.

Traps were retrieved at dawn; captured mosquitoes were separated and grouped by trap site. placed in cryogenic tubes, and stored in liquid nitrogen. Upon return to Dakar, mosquitoes were held at $-70^{\circ} \mathrm{C}$ until later being identified, counted, placed in monospecific pools of $\leq 100$ individuals, and processed for virus isolation.

Virus isolation and identification. Mosquitoes were tested for the presence of arboviruses by inoculating mosquito suspensions into cell culture and suckling mice. ${ }^{36}$ Monospecific pools of $\leq 100$ mosquitoes were triturated in chilled tissue-grinding dishes with $1 \mathrm{ml}$ of Hanks' balanced salt solution. Suspensions were clarified by centrifugation, inoculated into Ae. pseludoscutellaris (AP-61) cell cultures, and screened after 7-8 diays by immunofiuorescence, using various monovalent and polyvalent hyperimmune mouse ascitic fluids. ${ }^{3 i}$ Pools testing positive were confirmed by cell culture. The original mosquito pools of all samples that tested positive were confirmed by assay in suckling mice. Isolates from brain tissue were identified by complement fixation and neutralization tests at the World Health Organization Arbovirus Reference Center. Pasteur Institute in Dakar. ${ }^{36}$

Data analysis. Risk factors for seropositivity were analyzed by multiple logistic regression techniques. ${ }^{37}$ using the Statistix package (Analytical Software, St. Paul, MN). Results were based on asymptotically chi-squared G2 for unadjusted models. as well as for models adjusted for all factors. ${ }^{38}$ Clustering of seropositive residents within compounds was analyzed by the method of Walter. ${ }^{39}$ Statistically significant interactions between seropositive rates associated with risk factors and age or sex were sought. and when detected, served as a criterion for division into age- or sex-specific subgroups. Multiple regression techniques were applied to arcsinetransformed seroprevalences ${ }^{\text {th }}$ to evaluate the relationships between past infection in sheep and humans from the same compound. Reported $P$ values are two-tailed unless otherwise indicated.

\section{RESULTS}

Population. A total of 722 people five years of age or older in 83 compounds was identified within the study area during the observation period. Of these residents, $353(48.9 \%)$ agreed to participate. Either blood specimens $(n=66)$ or questionnaire data $(n=14)$ were inadequate for 80 persons: the remaining 273 residents $(114$ males and 159 females, $37.8 \%$ of the total pop- 
TABLE 1

Prevalence of anti-Rift Valley fever virus IgG by age group among humans sampled in Yonofere, Senegal during February-May 1989

\begin{tabular}{ccccc}
\hline & $\begin{array}{c}\text { Age range } \\
\text { (years) }\end{array}$ & \multicolumn{3}{c}{ \% seropositive (no. sampled) } \\
\cline { 3 - 5 } & & Total & Males & Females \\
\hline $5-19$ & & $14.2(127)$ & $16.4(55)$ & $12.5(72)$ \\
$20-39$ & $25.0(76)$ & $31.0(29)$ & $21.3(47)$ \\
$40-59$ & $32.7(49)$ & $36.4(22)$ & $29.6(27)$ \\
$60-79$ & $31.6(19)$ & $37.5(8)$ & $27.3(11)$ \\
$\geq 80$ & $100.0(2)$ & $0(0)$ & $100.0(2)$ & $20.1(159)$ \\
Total & $22.3(273)$ & $25.4(114)$ & $<0.001$ \\
$P$ value for linear trend* & $<$ & $<0.001$ & $<0.012$ & \\
\hline
\end{tabular}

* Unweighted logistic regression.

ulation) in 47 compounds $(44.6 \%)$ subsequently were included in the study.

Human antibody prevalence. Sixty-one residents $(22.3 \%)$ had anti-RVF virus IgG antibodies (Table 1). None tested positive for IgM antibody to this virus. The prevalence of IgG was similar for males $(25.4 \%)$ and females $(20.1 \%)$ $\left(\chi^{2}=1.08\right.$, degrees of freedom $[\mathrm{df}]=1, P=$ 0.30 ). Seroprevalence increased significantly with age for both sexes, more than doubling from the youngest age group ( $5-19$ years old) to the oldest ( $\geq 80$ years old) (Table 1 ).

Deaths and illnesses. A total of 16 human deaths in 15 study compounds during the previous two years were reported by compound chiefs; most people who died were either very young or elderly. Twelve deaths were associated with fever and three with hemorrhage. Two deaths were described that had a symptom complex compatible with RVF (bleeding and myalgia with headache or fever) and occurred during the rainy season when mosquitoes were abundant. The seroprevalences among surviving members of compounds where these two deaths occurred were $27 \%(\mathrm{n}=11)$ and $0 \%(\mathrm{n}=6)$. Overall, there was no statistical association between seropositivity in compound members and reported febrile illness in the same group.
Spatial patterns. To examine the spatial distribution of RVF virus infection, we compared antibody prevalences among all 37 compounds. The 61 seropositive persons came from 27 (73.0\%) of the compounds; $82.7 \%$ of the study population resided therein. Compounds were grouped according to the observed frequency of seropositive individuals within each; this distribution then was compared with that expected if seropositive residents were distributed at random. No evidence of clustering of infection within compounds was apparent (Table 2). The distribution of seropositive residents among compounds did not differ from that expected by chance $(P>0.50)$, nor were there more pairs of seropositive residents than expected $(P>0.05)$.

Correspondence between human and sheep antibody prevalence. To explore the relationship between seroprevalence among human compound residents and their sheep, we tested serum specimens of animals from 20 compounds for anti-RVF virus antibodies. (Flocks of the other study compounds were not bled because either the herder did not consent or we were unable to visit the compound when the flock was present in the village.) From a total of $\sim 1,100$ sheep, $375(\sim 34 \%)$ were tested. Overall, 113 $(30.1 \%)$ of tested sheep had IgG antibodies

TABLE 2

Lack of evidence of clustering of anti-Rift Valley fever virus $\operatorname{Ig} G$ among 273 humans inhabiting 37 compounds in Yonofere, Senegal

\begin{tabular}{|c|c|c|c|c|c|}
\hline & \multicolumn{5}{|c|}{ No. of seropositive residents per compound } \\
\hline & 0 & 1 & 2 & 3 & $\geq 4$ \\
\hline Observed & 10 & 9 & 10 & 4 & 4 \\
\hline Expected & 8.7 & 11.2 & 8.3 & 4.8 & 4.1 \\
\hline Observed - Expected* & 1.3 & -2.2 & 1.7 & -0.8 & -0.1 \\
\hline
\end{tabular}

* No clustering within compounds $(P>0.50$, by S. D. Walter test for aggregation in households). 
TABLE 3

Examples of reported activities unassociated with Rift Valley fever virus antibody among 273 humans sampled during February-May 1989 in Yonofere, Senegal

\begin{tabular}{|c|c|c|}
\hline Type & Activity or event & $\begin{array}{l}\text { Percentuse } \\
\text { experienuing }\end{array}$ \\
\hline Personal health & $\begin{array}{l}\text { Recent febrile illness } \\
\text { Visit health provider } \\
\text { Bitten by ticks }\end{array}$ & $\begin{array}{l}87.5 \\
60.1 \\
39.9\end{array}$ \\
\hline Providing health care & $\begin{array}{l}\text { Assist in human births } \\
\text { Prepare the dead for burial } \\
\text { Perform circumcisions } \\
\text { Perform tatooing/scarification }\end{array}$ & $\begin{array}{r}10.2 \\
8.8 \\
1.8 \\
1.5\end{array}$ \\
\hline Daily activities & $\begin{array}{l}\text { Visit village well } \\
\text { Care for children } \\
\text { Sleep near animals } \\
\text { Migrate with animals } \\
\text { Sleep outdoors }\end{array}$ & $\begin{array}{l}83.9 \\
80.2 \\
63.7 \\
68.1 \\
38.5\end{array}$ \\
\hline Agricultural production & $\begin{array}{l}\text { Remove ticks from animals } \\
\text { Take animals to pasture } \\
\text { Harvest crops } \\
\text { Cultivate millet } \\
\text { Brand animals } \\
\text { Take animals to veterinarian }\end{array}$ & $\begin{array}{l}85.1 \\
59.7 \\
57.5 \\
51.6 \\
51.3 \\
35.2\end{array}$ \\
\hline Food preparation and consumption & $\begin{array}{l}\text { Drink animal milk } \\
\text { Cook meat } \\
\text { Drink sick animal milk } \\
\text { Butcher animals }\end{array}$ & $\begin{array}{l}97.4 \\
90.8 \\
48.7 \\
27.1\end{array}$ \\
\hline
\end{tabular}

(range among compounds 0-66.7\%), including three $(0.8 \%)$ that were IgM positive. Among the 239 human residents of the same 20 compounds. $187(78.2 \%)$ were tested; $42(22.5 \%)$ of those were seropositive (range $0-37.5 \%$ ). No systematic relationship between the seroprevalence among the human inhabitants of compounds and that of their sheep could be identified (Student's $t=0.36$, df $=18, P=0.72$ ).

Risk factors. Most of the numerous possible risk factors for past exposure to RVF virus that were assessed were unassociated with the presence of antibody (Table 3). Although we previously demonstrated that Crimean-Congo hemorrhagic fever (CCHF) virus infection in this population was associated with tick bites, ${ }^{25}$ no relationship between reported tick exposure and RVF virus was found. Similarly, other potential risk factors involving outdoor activities, exposure to vectors or infected hosts (sleeping outdoors or near animals), contact with the blood of healthy humans (births, circumcisions, tatooing) or exposure to animal blood (branding, slaughter, cooking meat) were not associated with evidence of past RVF virus infection. Finally, drinking healthy or sick animal milk did not increase risk (Table 3 ).
Three activities did emerge as highly predictive of previous $\mathrm{RVF}$ virus infection: nursing sick people, assisting animals during abortions/ births, and treating sick animals (Table 4). Sexspecific unadjusted logistic regression of $R V F$ virus antibody as a function of reported activities suggested that males who nursed sick people and females who treated sick animals had more often been infected with RVF virus $(P<0.001)$ (Table 4 ). In addition, males who reported assisting in animal abortions or births more frequently were seropositive $(P=0.02)$. Similarly for males, previous infection with CCHF virus was highly predictive of RVF virus seropositivity $(P<0.001)$. Seroprevalence increased with age for both sexes, a trend that was stronger for females $(P=0.005)$. Because the simple, unadjusted logistic regression models did not evaluate possible confounding among risk factors, we examined adjusted models that simultaneously tested for these and other activities or characteristics. The risk factors that were most highly associated with RVF virus seropositivity remained the same in this analysis (Table 4). Less prominent risk factors for males (age, treating sick animals, assisting. animals in births/ abortions) were not associated with RVF virus 
TABLE 4

Reported activities or characteristics significantly associated with Rift Valley fever (RVF) virus IgG among humans in Yonofere, Senegal

\begin{tabular}{|c|c|c|c|c|}
\hline \multirow{3}{*}{$\begin{array}{l}\text { Activity or } \\
\text { characteristic* }\end{array}$} & \multicolumn{4}{|c|}{$P$ valuet for } \\
\hline & \multicolumn{2}{|c|}{ Males $(n=108)$} & \multicolumn{2}{|c|}{ Females $(n=148)$} \\
\hline & Unadjusted & Adjusted & Unadjusted & Adjusted \\
\hline Nurse sick people & 0.001 & 0.004 & 0.19 & 0.89 \\
\hline Treat sick animals & 0.03 & 0.92 & 0.001 & 0.007 \\
\hline $\begin{array}{l}\text { Assist animals in } \\
\text { birth/abortion }\end{array}$ & 0.02 & 0.06 & 0.44 & 0.73 \\
\hline Age & 0.04 & $>0.99$ & 0.005 & 0.03 \\
\hline $\mathrm{CCHF}$ virus $\mathrm{IgG}$ & 0.003 & 0.01 & 0.23 & 0.42 \\
\hline
\end{tabular}

* Results of activities reported from questionnaires or by persons testing positive for Crimean-Congo hemorrhagic fever (CCHF) virus IgG; age is grouped as $5-19,20-39,40-59$, and $\geq 60$ years old.

$\dagger P$ values from logistic regression of RVF virus antibody as a function of each individual activity or characteristic (unadjusted), and as the last variable in a model containing all five risk factors (adjusted).

seropositivity after adjustment. No relationship was identified between the compounds used by seropositive men and the locations of hemorrhagic febrile deaths.

To examine further the age-associated prevalence of RVF viral antibodies among females who reported treating sick animals, we compared the age group-specific odds ratios (ORs) of past infection among both animal treaters and nontreaters: those ORs increased with age, suggesting that other exposures also augmented risk of infection (Table 5). However, for each age group, females who reported that they treated sick animals had ORs that were 2.8-5.7-fold greater than those who did not. Similarly, the ORs for males who assisted with animal births or abortions, nursed sick people, or had previous CCHF virus exposure were 4.7-6.8 times those of males who did not (Table 5). All RVF virus seropositive males reported at least one of the behavioral risk factors or was CCHF virus antibody positive.

$$
\text { TABLE } 5
$$

Age- and/or risk-specific odds ratios for Rift Valley fever (RVF) virus antibody among 148 females and 108 males at Yonofere, Senegal

\begin{tabular}{|c|c|c|c|c|c|}
\hline Risk factor & $\underset{\text { (years) }}{\text { Age range }}$ & Exposure* & No. & $\%$ positive & ORł \\
\hline \multicolumn{6}{|l|}{ Females } \\
\hline Treating sick animals & $\begin{array}{r}5-19 \\
20-39 \\
40-59 \\
\geq 60\end{array}$ & No & $\begin{array}{r}62 \\
29 \\
15 \\
9\end{array}$ & $\begin{array}{r}8.1 \\
13.8 \\
20.0 \\
33.3\end{array}$ & $\begin{array}{l}1.0 \\
1.8 \\
2.9 \\
5.7\end{array}$ \\
\hline & $\begin{array}{c}5-19 \\
20-39 \\
40-59 \\
\geq 60\end{array}$ & Yes & $\begin{array}{r}6 \\
14 \\
12 \\
1\end{array}$ & $\begin{array}{r}33.3 \\
35.7 \\
41.7 \\
100.0\end{array}$ & $\begin{array}{l}5.7 \\
6.3 \\
8.1 \\
>>>\end{array}$ \\
\hline \multicolumn{6}{|l|}{ Males (all ages) } \\
\hline $\begin{array}{l}\text { Assist with } \\
\text { animal births } \\
\text { or abortions }\end{array}$ & - & $\begin{array}{l}\text { No } \\
\text { Yes }\end{array}$ & $\begin{array}{l}34 \\
74\end{array}$ & $\begin{array}{r}8.8 \\
31.1\end{array}$ & $\begin{array}{l}1.0 \\
4.7\end{array}$ \\
\hline $\begin{array}{l}\text { Nurse sick } \\
\text { people }\end{array}$ & - & $\begin{array}{l}\text { No } \\
\text { Yes }\end{array}$ & $\begin{array}{l}72 \\
36\end{array}$ & $\begin{array}{l}13.9 \\
44.4\end{array}$ & $\begin{array}{l}1.0 \\
5.0\end{array}$ \\
\hline $\begin{array}{l}\text { CCHF§ virus } \\
\text { antibodies }\end{array}$ & $\begin{array}{l}- \\
-\end{array}$ & $\begin{array}{l}\text { No } \\
\text { Yes }\end{array}$ & $\begin{array}{l}95 \\
13\end{array}$ & $\begin{array}{l}18.9 \\
61.5\end{array}$ & $\begin{array}{l}1.0 \\
6.8\end{array}$ \\
\hline
\end{tabular}

* Exposed or not exposed to reported or tested risk factor.

$\div$ Percentage testing positive for RVF virus IgG.

$\doteqdot$ Exposure-specific odds ratio (OR) for RVF virus antibody compared with the absence of exposure for that group (OR $=1.0$ ). $\S \mathrm{CCHF}=$ Crimean-Congo hemorrhagic fever. 
TABLE 6

Wosquitoes trapped at Yonofere, Senegal during July 1989-December 1990

\begin{tabular}{|c|c|c|c|c|c|}
\hline \multirow{2}{*}{$\begin{array}{c}\text { Genus } \\
\text { species }\end{array}$} & \multicolumn{2}{|c|}{1989} & \multicolumn{2}{|c|}{1990} & \multirow[b]{2}{*}{ Total } \\
\hline & No. & Mean" & No. & Mean* & \\
\hline \multicolumn{6}{|l|}{ Aeiles } \\
\hline apicoargenteus & $\because 0$ & - & 1 & $<0.1$ & 1 \\
\hline argenteopunctatus & 9 & 0.2 & 0 & - & 9 \\
\hline dal:ieli $\dagger$ & 99 & 2.4 & 12 & 0.5 & 111 \\
\hline fowleri & 26 & 0.6 & 0 & - & 26 \\
\hline mcintoshi & 37 & 0.9 & 0 & - & 37 \\
\hline metallicus & 1 & $<0.1$ & 0 & - & 1 \\
\hline minutus & 98 & 2.3 & 0 & _ & 98 \\
\hline ochraceus & 191 & 4.5 & 42 & 1.8 & 233 \\
\hline sudanensis & 19 & 0.5 & 4 & 0.2 & 23 \\
\hline unilineatus & 4 & 0.1 & 7 & 0.3 & 11 \\
\hline vexuns & 1,391 & 33.1 & 550 & 23.9 & $1,9+1$ \\
\hline (Subtotal) & $(1,875)$ & $(44.6)$ & (616) & $(26.8)$ & $(2,491)$ \\
\hline \multicolumn{6}{|l|}{ Anophetes } \\
\hline gambiale complex & 33 & 0.8 & 0 & - & 33 \\
\hline pharoensist & 30 & 0.7 & 4 & 0.2 & 34 \\
\hline rufipes & 6 & 0.1 & 4 & 0.2 & 10 \\
\hline siemanni & 27 & 0.6 & 12 & 0.5 & 39 \\
\hline (Subtotal) & (96) & (2.3) & (20) & $(0.9)$ & (116) \\
\hline \multicolumn{6}{|l|}{ Culex } \\
\hline antennatus ${ }^{\dagger}$ & 33 & 0.8 & 3 & 0.1 & 36 \\
\hline bitaeniorhynchus & 5 & 0.1 & 1 & $<0.1$ & 6 \\
\hline ethiopicus & 7 & 0.2 & 0 & - & 7 \\
\hline ne'tivei & 15 & $0 . t$ & 13 & 0.6 & 28 \\
\hline poicillipes & 56 & 1.3 & 75 & 3.3 & 131 \\
\hline sitiens group & 73 & 1.7 & 0 & - & 73 \\
\hline tigripe's & 1 & $<0.1$ & 0 & - & 1 \\
\hline tritaeniorhynchus & 33 & 0.8 & 19 & 0.8 & 52 \\
\hline (Subtutal) & $(223)$ & (5.3) & (111) & $(4.8)$ & $(33+)$ \\
\hline \multicolumn{6}{|l|}{ Mansonia } \\
\hline africanat & 4 & 0.1 & 0 & - & 4 \\
\hline uniformis $\ddagger$ & 6 & 0.1 & 8 & 0.3 & 14 \\
\hline (Subtotal) & (10) & $(0.2)$ & $(8)$ & (0.3) & (18) \\
\hline \multicolumn{6}{|l|}{ Mymomyia } \\
\hline hispida & 0 & - & 21 & 0.9 & 21 \\
\hline lacustris & 0 & - & 1 & $<0.1$ & 1 \\
\hline (Subtotal) & (0) & $(-)$ & (22) & $(1.0)$ & (22) \\
\hline \multicolumn{6}{|l|}{ Uranotaenia } \\
\hline balfouri & 0 & - & 3 & 0.1 & 3 \\
\hline Total & 2,204 & 52.5 & 780 & 33.8 & 2,984 \\
\hline
\end{tabular}

* Mean number of monquitoes per trapnight from July-December.

$\dagger$ Species previously found naturally infected with Rift Valley fever virus that were cited by Meegan and Bailey:

From Logan and others. ${ }^{+1}$

Mosquito species, seasonality, and virus infection. A total of 2,984 mosquitoes comprising 28 species from six genera were found at the four stations where trapping occurred (Table 6). Aedes spp., particularly Ac. vexuns, were most ahundant. In addition, various $C$ ulex, Anopheles, Mansonia, Mymomyia, and Uranotaenia were captured. Studies from East Africat have shown five of these species to be naturally infected with RVF virus there (Table 6).

A subsample of 2,956 mosquitoes that could be identified to species was placed in 142 monospecific pools and tested for arboviruses. No isolates of RVF virus were made. Five isolates of three viruses from the family Flaviviridae were obtained from mosquito pools: Wesselsbron vi- 
rus from Ae. ochraceus (August 1989), Bagaza virus from Mimomyia hispida (August 1990), and West Nile virus isolated once from $C x$. antennatus (August 1990) and twice from Ae. vexans (October 1990). ${ }^{36}$

The temporal pattern of mosquito abundance was highly seasonal and corresponded closely with that of rainfall (Figure 2). Most mosquitoes appeared during July-October, shortly after the first rains. Differences between the two years in the commencement and total amount of rainfall were reflected in mosquito emergence and overall abundance. Mosquitoes were ẩlready abundant when sampling was begun in July 1989; one year later, however, average abundance did not peak until October, reflecting less rainfall and later-than-usual first rains in 1990. In both years, as the rainy season ended the abundance of mosquitoes declined to virtually nil (Figure 2). Our samples were insufficient to evaluate differences in emergence patterns among mosquito species. Most mosquitoes were active during a few months shortly following the commencement of the rainy season.

\section{DISCUSSION}

This study represents the first systematic examination of human risk factors associated with endemic Rift Valley fever and suggests that contact with infected animals or humans may be an important mode of transmission under nonepidemic conditions. Most previous reports on the epidemiology of RVF have described characteristics of infected populations during or shortly after epidemic transmission. ${ }^{1-5}$ In our study, we bled flocks of sheep every two months. ${ }^{42}$ from four compounds before, during, and after the nearby Mauritanian epidemic, ${ }^{7-9}$ but epizootic RVF virus activity was not detected (unpublished data). Furthermore, IgM was not found in samples that we collected from human subjects and was found only occasionally in samples from sheep. In addition, residents often sought help for many illnesses during our visits to the study site $(\sim 5$ days each month), but no symptoms suggesting either hemorrhagic fever, encephalitis, or ocular disease were observed; nonspecific febrile syndromes compatible with the more common RVF clinical presentation were rare. Thus, our study analyzed exposure at a site where RVF virus transmission appeared to be endemic.

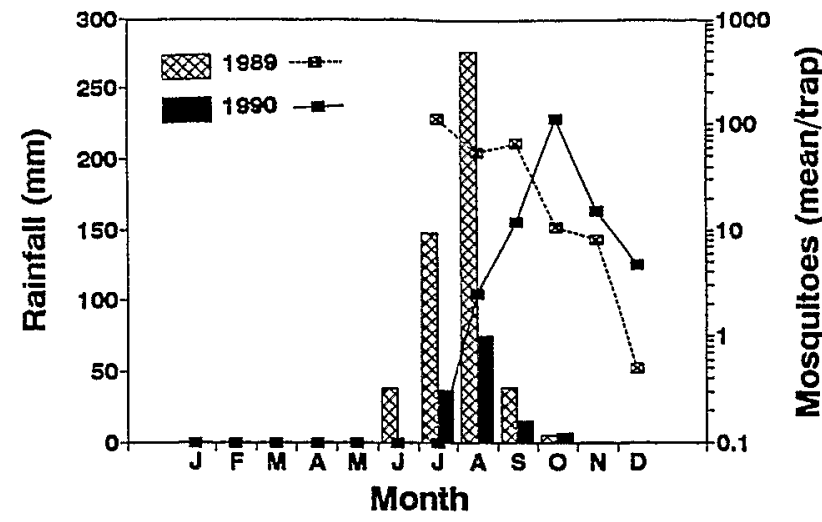

FIGURE 2. Monthly rainfall (bars) and mean number of mosquitoes per trap (lines) sampled in Yonofere, Senegal during 1989-1990. Mosquito samples (log scale) were begun in July 1989 and continued through December 1990.

We sampled a large percentage of this rural population, and althoùgh our sample was not random, it allowed us to estimate the extent of past RVF virus infection there. Transmission incidence appears to have been at or above levels reported for most other parts of Africa. The overall prevalence of human RVF virus antibody was greater than that generally reported from other sites where RVF has been considered endemic. Serologic surveys in the absence of human disease have reported RVF viral antibody prevalences ranging from $<1 \%$ to $<10 \%$ in parts of Angola, ${ }^{43}$ Botswana, ${ }^{44}$ Central African Republic, ${ }^{45-47}$ Nigeria, ${ }^{11,48}$ Gabon, ${ }^{14}$ Guinea, ${ }^{13}$ Kenya, ${ }^{49}$ Mali, ${ }^{14}$ and Sudan. ${ }^{50}$ Our survey among residents of a Peul village in northern Senegal found that overall, nearly one-quarter of the people had been infected previously by RVF virus. The prevalence of IgG antibodies increased significantly with age to include more than onethird of persons $\geq 60$ years of age, also suggesting long-term exposure in a situation of endemic transmission. Although males and females had similar antibody prevalences overall, the patterns of seroprevalence and risk associations differed, suggesting that the nature of exposure might be dissimilar, possibly reflecting gender-specific roles.

Sheep in our study were frequently infected as evidenced by IgG prevalence rates greater than those reported from nearby Burkina Faso ${ }^{51}$ or Nigeria. " Furthermore, about $1 \%$ of the sheep had IgM antibodies, providing evidence of recent infection. The average age of sheep in Senegal is less than three years, ${ }^{52}$ further indicating 
that IgG-positive animals had been recently exposed. A Senegal-wide, randomized serosurvey of 1,715 sheep and goats undertaken just prior to our study demonstrated considerable variation in seroprevalence among animals from those regions. ${ }^{15}$ In that study, the antibody prevalence in sheep from the same governmental district in which Yonofere is located was $40 \%$, the highest among 22 districts examined. We found a similar prevalence in the present study, suggesting that conditions in this region are conducive to elevated, endemic RVF virus transmistsion.

Despite the relatively high antibody prevalences in both humans and sheep, the spatial patterns of past RVF virus infections differed. Sheep seroprevalences were not related to those of humans inhabiting the same compounds, suggesting different mechanisms or histories of exposure. Since the age structure of this human population differed from that of the sheep. human antibody rates should have reflected past exposure during decades rather than years. Accordingly, infection incidence in sheep would be many-fold greater than that in humans.

No spatial pattern indicating focal infection within compounds or huts, or between spouses was observed. Although nursing sick people was associated with increased risk of infection for males, no evidence of clustering within compounds emerged such as would be expected if infection were regularly spread through casual contact among persons living together. Further analysis of antibody prevalence in relation to environmental characteristics would be instructive to determine whether geomorphic or vegetation characteristics of the habitat may be related to past RVF infection. ${ }^{53}$

Contact with potentially infective tissues emerged as the principal human risk factor associated with previous RVF virus exposure. Males who reportedly nursed sick people or assisted animals that were giving birth or aborting were infected more often, as were females who treated sick animals. These behaviors could be risk factors for both sexes, or perhaps they are associated with other risk behaviors that were not measured. For example, most females reported nursing sick people; however, the types of illnesses treated may have varied in a manner that placed only certain individuals at risk. Among males, most reported that they treated sick animals, yet those who assisted in animal births and abortions may have been more likely to treat illnesses that led to RVF virus exposure.

The association of RVF among females treating sick animals and among males assisting in animal births/abortions is consistent with suggestions from previous studies. The finding, however. that males who reported nursing sick humans also had a high prevalence of RVF viral antibody, even after statistical adjustment, is puzzling. This strong association is inconsistent with previous reports, none of which showed evidence of nosocomial or person-to-person spread. In a related study of people in Yonofere. .5 we found that herding activity among males was associated with CCHF virus antibody. which apparently serves as a marker for RVF virus antibody in this study. Perhaps nursing sick humans is a marker for some other behavior or exposure that represents the true risk of infection. Prospective studies directed specifically at this question would be instructive.

Other reports have suggested that RVF virus may be directly transmitted under certain conditions. Abattoir workers in South Africa, particularly those whose job involved handling diseased carcasses, have been shown to be at increased risk of $\mathrm{RVF}$ virus exposure..$^{54} \mathrm{~A}$ recent study of Kenyan herdsmen from RVF-endemic areas reported that $40 \%$ had RVF virus-specitic IgG antibody. ${ }^{55}$ Numerous accidental laboratory infections further support the possibility that contact or aerosol contamination with animals or their tissues may lead to transmission in natural settings. ${ }^{19-21}$ Furthermore, experimental studies with sheep have shown that RVF virus can be recovered from the spleen and liver up to threeweeks postinfection. ${ }^{56}$ These diverse findings are consistent with our results that demonstrate an association between exposure to potentially infective tissues and RVF virus infection among humans in this rural setting.

Males who previously were infected with CCHF virus were more likely to have been infected with RVF virus. Although the high prevalence of CCHF viral antibodies in this population indicates frequent infection,,$^{25}$ the different vectors and transmission cycles of these two arboviral agents suggest that exposures may not be similar. Perhaps this strong association between CCHF and RVF reflects the linkage of a group of exposures common to males such as increased outdoor activity, general exposure to 
arthropod vectors, animal slaughter, or other forms of animal contact.

Mosquito activity was strikingly seasonal, increasing rapidly after the rainy season began and declining as the rains ended. Most activity took place during July to October, several months before our serologic samples were obtained. Five of the 28 mosquito species captitred in our study previously had been found naturally infected with RVF virus, ${ }^{2,40}$ including several isolations in Senegal from Ae. dalzieli. ${ }^{36}$ Although three other arboviruses were isolated from pools of four mosquito species, RVF virus was not found in our sample. For this reason and because species-specific human biting by mosquitoes was not measured, the role of these potential vectors in RVF virus transmission could not be evaluated directly. Prospective studies of the mosquito populations combined with virus isolation attempts are needed to implicate West African species as vectors of RVF virus.

Our retrospective study provides information on the prevalence of infection and modes of transmission among a group of subsistence herding-agriculturalists of West Africa. Most other studies of the epidemiology of human RVF have investigated slaughterhouse workers, farmers, or ranchers in areas of southern or eastern Africa settled principally by non-native colonists. Hoogstraal's ${ }^{57} 1978$ observation seems poignant: "Indigenous Áfrican peoples have been overlooked in relation to RVF epidemiology. One is left wondering whether many rural Africans develop early immunity to RVF virus, either from bites of infected mosquitoes. . .or from contact with infected animals." Further research from this perspective will undoubtedly shed light on the true incidence, clinical severity, and public health impact of RVF in these populations.

Acknowledgments: We are grateful to Ousmane Sow, Chief of Yonofere, whose insight, curiosity, and active cooperation added immeasurably to our studies; we dedicate this report to him following his untimely death. Charles L. Bailey, Jean-Pierre Digoutte, Susan P. Fisher-Hoch, and Joseph B. McCormick provided encouragement and constructive discussions. The technical assistance of Marie-Armande Calvo-Wilson, Abdoulaye Diouf, Mireille Mondo, Ibrahima Samb, Beth A. Schmidt, and Rougui Sylla was invaluable. We are grateful to James M. Meegan, Robert B. Tesh, and Robert E. Shope for reading and considerabiy improving the manuscript.

Financial support: This work was supported by the U.S. Army Medical Research Institute of Infectious
Diseases (grants DAMD-17-87-G-7003 and DAMD90-Z-0020), the Epidemiology Program Office, Centers for Disease Control and Prevention, and the MacArthur Foundation (grant 9008073A Health).

Authors' addresses: Mark L. Wilson, Yale Arbovirus Research Unit, Department of Epidemiology and Public Health, Yale University School of Medicine, PO Box 208034, New Haven, CT 06520-8034. Louisa E. Chapman and C. J. Peters, Centers for Disease Control and Prevention, 1600 Clifton Road, Atlanta, GA 30333. David B. Hall, Boehringer Ingelheim Pharmaceuticals, Inc., 900 Ridgebury Road, Ridgefield, CT 06877. Elizabeth A. Dykstra, Department of Entomology, Texas A \& M University, College Station, TX 77843. Khalilou Ba, ORSTOM, BP 1386, Dakar, Senegal. Herve G. Zeller and Moumouni Traore-Lamizana, Institut Pasteur, BP 220 Dakar, Senegal. Jean-Paul Hervy, ORSTOM, BP 5045, 34032 Montpellier, France. Kenneth J. Linthicum, USAMC-AFRIMS, APO San Francisco, CA 96346-5000.

Reprint requests: Mark L. Wilson, Yale Arbovirus Research Unit, Department of Epidemiology and Public Health, Yale University School of Medicine, PO Box 208034, New Haven, CT 06520-8034.

\section{REFERENCES}

1. Peters CJ, Meegan JM, 1981. Rift Valley fever. Steele JH, ed. CRC Handbook Series in Zoonoses. Boca Raton, FL: CRC Press, 403-120.

2. Meegan JM, Bailey CL, 1988. Rift Valley fever. Monath TP, ed. Arboviruses Epidemiology and Ecology. Volume IV. Boca Raton, FL: CRC Press, 51-76.

3. Easterday BC, 1965. Rift Valley fever. Adv Vet Sci 10: 65-127.

4. Shimshony A, Barzilai R, 1983. Rift Valley fever. Adv Vet Sci Comp Med 27: 347-425.

5. Meegan JM, 1981. Rift Valley fever in Egypt. An overview of the epizootic in 1977 and 1978. Contrib Epidemiol Biostat 3: 100-113.

6. Davies FG, 1975. Observations on the epidemiology of Rift Valley fever in Kenya. $J H_{i} \cdot g$ (Camb) 75: 219-230.

7. Digoutte JP, Peters CJ, 1989. General aspects of the 1987 Rift Valley fever epidemic in Mauritania. Res Virol 140: 27-30.

8. Jouan A, Coulibaly I, Adam F, Philippe B, Riou $\mathrm{O}$, Leguenno B, Christie R, Ould Merzoug N, Ksiazek T, Digoutte JP, 1989. Analytical study of a Rift Valley fever epidemic. Res Virol 140: 175-186.

9. Ksiazek TG, Jouan A, Meegan JM, LeGuenno B, Wilson ML, Peters CJ, Digoutte JP, Guillaud M, Merzoug NO, Touray OI, 1989. Rift Valley fever among domestic animals in the recent West African outbreak. Res Virol 140: 67-77.

10. Saluzzo JF, Digoutte JP, Chartier C, Martinez D, Bada R, 1987. Focus of Rift Valley fever in southern Mauritania. Lancet i: 504.

11. Fagbami AH, Tomori O, Kemp GE, 1973. A survey of Nigerian domestic and wild animals for 
serum neutralizing antibody to indigenous Rift Valley fever virus. Nigerian Vet $J$ 2: 45-48.

12. Saluzzo JF, Digoutte JP, Cornet $M$, Baudon $D$, Roux J. Robert V, 1984. Isolation of CrimeanCongo haemorrhagic fever and Rift Valley fever viruses in Upper Volta. Lancet $i: 1179$.

13. Meegan JM. Digoutte JP. Peters CJ. Shope RE. 1983. Monoclonal antibodies identify Zinga virus as Rift Valley fever virus.' Lancet $i: 641$.

14. Findlay $\mathrm{AH}$, Stefanopoulo GJ, McCallum FO, 1936. Presence d'anticorps contre le virus de la vallee du Rift dans le sang des Africains. Bull Soc Pathol Exot 29: 286-296.

15. Guillaud M, LeGıenno B. Wilson 1 IL, Desoutter D. Gonzalez JP, Digoutte JP, 1988. Prevalence en anticorps contite le virus de la fievie de la vallee du Rift chez les petits ruminants du Senegal. Ann Inst Pasteur/Virol 139: $455-459$.

16. McIntosh BM. Jupp PG. 1981. Epidemiological aspects of Rift Valley fever in South Africa with references to vectors. Contrib Epidemiol Biostat 3: 92-99

17. Meegan JM. Khalil GM, Hoogstraal H, Adham FK, 1980. Experimental transmission and field isolation studies implicating Culex pipiens as a vector of Rift Valley fever in Egypt. Am J Trop Med Hyg 29: 1405-1410.

18. McIntosh BM, Jupp PG, dos Santos 1. Rowe AC, 1983. Field and laboratory evidence implicating Culex zombaensis and Aedes circumluteolus as vectors of Rift Valley fever virus in coastal South Africa. S Afr J Sci 79: 61-64.

19. Smithburn KC, Mihaffy AF, Haddow AJ, Kitchen SF, Smith JF, 1949. Rift Valley fever: accidental infections among laboratory workers. $J \mathrm{Im}^{-}$ munol 62: 213-227.

20. van Velden DJJ, Meyer JD, Oliver J, Gear JHS, McIntosh B, 1977. Rift Valley fever affecting humans in South Africa: a clinicopathological study. S Afr Mi'd J 51: 867-871.

21. Gear J, de Meillon B, Measroch V, Harwin R, Davis DHS, 1951. Rift Valley fever in South Africa. 2. The acurrence of human cases in the Orange Free State, the North-western Cape Province, the Western and Southern Transvaal. B. Field and laboratory investigations. $S A f r$ Med J 25: 908-912.

22. Linthicum KJ, Davies FG, Kairo A, Bailey CL. 1985. Rift Valky fever virus (family Bunyaviridae, genus Phlebovirus). Isolations from Diptera collected during an inter-epizootic period in Kenya. J Hyg (Camb) 95: 197-209.

23. Davies FG, Linthicum KJ, James AD, 1985. Rainfall and epizootic Rift Valley fever. Bull World Health Organ 0.: 941-963.

24. Hoogstraal H, Mcegan JM, Khalil GM, Adham FK, 1979. The Rift Valley fever epizootic in Egypt 1977-1978. 2. Ecological and entomological studies. Trums $R$ Soc Trop Med Hyg 73: $624-629$.

25. Chapman LE, Wilion ML, Hall DB. LeGuenno B, Dykstra EA. Bal K. Fisher-Hoch SP, 1991. Risk factors for Crimean-Congo hemorrhagic fever in rural northern Senegal. J Infect Dis 164: 686692.

26. Leroux M, 1983. Climat. Pelissier P. ed. Atlas du Senegal. Second edition. Paris: Les Editions Jeune Afrique, 12-17.

27. Toure O, Arpaillange J, 1986. Peul du Ferlo. Paris: Jacques London, 1-79.

28. Ndiaye P, 1983. Vegetation et faune. Pelissier P, ed. Atlas du Senegal. Second edition. Paris: Les Editions Jeune Afrique, 18-21.

29. Mbow R, 1983. Peuplement et ethnies. Pelissier P, ed. Atlas du Senegal. Second edition. Paris: Les Editions Jeune Afrique, 20-21.

30. Meegan JM, Yedloutschnig RJ, Peleg BA, Shy J, Peters CJ, Walker JS. Shope RE. 1987. Enzyme-linked immunosorbent assay for detection of antibodies to Rift Valley fever virus in ovine and bovine sera. Am $J$ Vet Res 48: 1138-1141.

31. Meegan JM, LeGuenno F, Ksiazek TG, Jouan A, Knauert F, Digoutte JP, Peters CJ, 1989. Rapid diagnosis of Rift Valley fever: comparison of methods for the direct detection of viral antigen in human sera. Res tirol 140: 59-65.

32. Ackermann E, 1936. Dambos in Nordrhodesien. Wissenshaftl Veroffentlichungen Mus Landerkunde Leipzig 4: 147-157.

33. Linthicum KJ, Davies FG. Bailey CL. Kairo A, 1983. Mosquito species succession in a dambo in an East African forest. Mosq New's 43: 464470 .

34. Linthicum KJ. Davies FG, Kairo A. 1984. Observations of the biting activity of mosquitoes at a flooded dambo in Kenya. Mosq New's 4. 595598.

35. Linthicum KJ, Davies FG, Bailey CL, Kairo A. 1984. Mosquito species encountered in a flooded grassland dambo in Kenya. Mosq News 44: 228-232.

36. Digoutte JP, ed., 1991. Centre Collaborateur OMS de Reference et de Recherche pour les Arbovirus. Rapport Annuel. Dakar, Senegal: Institut Pasteur.

37. Seigel S, 1956. Nonparametric Statistics for the Behavioral Sciences. New York: McGraw-Hill.

38. McCullagh P, Nelder JA, 1983. Generalized Linear Models. London: Chapman and Hall.

39. Walter SD, 1974. On the detection of household aggregation of disease. Biometrics 30: 525538.

40. Sokal RR, Rohlf FJ, 1981. Biometry. New York: Freeman.

41. Logan TM, Linthicum KJ, Davies FG, Binepal YS, Roberts CR, 1991. Isolation of Rift Valley fever virus from mosquitoes (Diptera: Culicidae) collected during an outbreak in domestic animals in Kenya. $J$ Med Entomol 28: 293-295.

42. Wilson ML, Gonzalez JP, LeGuenno B, Cornet JP Guillaud M, Calvo MA, Digoutte JP, Camicas JL. 1990. Epidemiology of Crimean-Congo hemorrhagic fever in Senegal: temporal and spatial patterns. Arch Virol (suppl 1): 323-340.

43. Kokernot RH, Casaca VMR, Weinbren MP, MLIntosh BM, 1965. Survey for antibodies against arthropod-borne viruses in the sera of indige- 
nous residents of Angola. Trans $R$ Soc Trop Med Hyg 59: 563-570.

44. Kokernot RH, Szlamp EL, Levitt J, McIntosh BM, 1965. Survey for antibodies against arthropodborne viruses in the sera of indigenous residents of the Caprivi Strip and Bechuanaland Protectorate. Trans R Soc Trop Med Hyg 59: 553562.

45. Gonzalez JP, McCormick JB, Saluzzo JF, Georges AJ, 1983. Les fievres hemorragique africaines d'origine viral. Contribution a leur etude en Republique centrafricaine. Cah ORSTOM Ser Entomol Med Parasitol 21: 119-130.

46. Georges AJ, Abdul-Wahid SA, Meunier DY, Georges-Courbot MC, Saluzzo $\mathrm{gF}$, Peters CJ, 1983. Serological evidence of endemic Zinga virus and Rift Valley fever virus in Central African Republic. Lancet $i$ : 1388.

47. Meunier DMY, Johnson ED, Gonzalez JP, Georges-Courbot MC, Madelon MC, Georges AJ, 1987. Donnees serologiques actuelles sur les fievres hemorragiques virales en Republique centrafricaine. Bull Soc Pathol Exot 80: 51-61.

48. Tomori O, Fabiyi A, Sorungbe A, Smith A, McCormick JB, 1988. Viral hemorrhagic fever antibodies in Nigerian populations. Am $J$ Trop Med Hyg 38: 407-410.

49. Johnson BK, Ocheng D, Gichogo A, Okiro M, Libondo D, Tukei PM, Ho M, Mugambi M, Timms GL, French M, 1983. Antibodies against haemorrhagic fever viruses in Kenya populations. Trans $R$ Soc Trop Med Hyg 77: 731-733.

50. Saleh AS, Mohammed KA, Hassan MM, Bucci
TJ, Meegan JM, 1981. Antibodies to Rift Valley fever virus in the human population of Sudan. Trans $R$ Soc Trop Med Hyg 75: 129-130.

51. Akakpo AJ, Some MJ, Bornarel P, Jouan A, Gonzalez JP, 1989. Epidemiologie de la fievre de la Vallee du Rift en Afrique de l'ouest. I. Enquete serologique chez les ruminants domestiques au Burkina Faso. Bull Soc Pathol Exot 82: 321331.

52. Wilson ML, LeGuenno B, Guillaud M, Desoutter D, Gonzalez JP, Camicas JL, 1990. Distribution of Crimean-Congo hemorrhagic fever viral antibody in Senegal: environmental and vectorial correlates. Am J Trop Med Hyg 43: 557-566.

53. Linthicum KJ, Bailey CL, Davies FG, Tucker CJ, 1987. Detection of Rift Valley fever viral activity in Kenya by satellite remote sensing imagery. Science 235: 1656-1659.

54. Chambers PG, Swanepoel R, 1980. Rift Valley fever in abattoir workers. Cent Afr J Med 26: 122-126.

55. Logan TM, Davies FG, Linthicum KJ, Ksiazek TG, 1992. Rift Valley fever antibody in human sera collected after an outbreak in domestic animals. Trans R Soc Trop Med Hyg 86: 202-203.

56. Yedloutschnig RJ, Dardiri AH, Walker JS, 1981. Persistance of Rift Valley fever virus in the spleen, liver, and brain of sheep after experimental infection. Contrib Epidemiol Biostat 3: 72-76.

57. Hoogstraal H, 1978. Rift Valley fever: an historical perspective. $J$ Egypt Public Health Assoc 53: $129-135$. 